6. Gurr, M. I. Lipid metabolism in man [Text] / M. I. Gurr // Proc. Nutc. Soc. - 1988. - Vol. 47, № 3. - P. 277 - 285.

7. Korzhenevskii D.A., Kuptsov V.N.,. Mityanina V.A,. Selishcheva A.A, Saveliev S.V. Identification of the Individual Molecular Species of Ceramides Derived from
Human Erythrocytes using HPLC/MS and HPLC/MS/MS.

// J. Anal. Chem. - 2011. - V. 66. - P. 1270 - 1275.

8. Tang, J. H. Metabolism of phospholipids on erythrocyte membranes [Text] / J. H. Tang, Y. Q. Lu // Sheng. Li. Hsueh. Chin. Chan. - 1990. - Vol. 21, №1. -P. 31 -35.

УДК $616.1 / .9$

https://doi.org/10.52692/1857-0011.2021.3-71.16

\title{
REMOTE RESULTS OF TREATMENT IN PATIENTS WITH PULMONARY TUBERCULOSIS AND PREVIOUS INEFFECTIVE THERAPY
}

\author{
Dmitriy Sergeevich RYASENSKIY, Candidate of Medical Sciences, Associate Professor at the Department of \\ Phthisiology \\ Alexander Vladimirovich ASEEV, Doctor of Medical Sciences, Head of the Department of Phthisiology \\ Akhmed Ibragimovich ELGALI, Assistant at the Department of Phthisiology
}

Tver State Medical University of the Ministry of Health of the Russian Federation, Department of Phthisiology, 170100, Tver, Russia

\section{Summary.}

Until recently, bedaquiline and linezolid were relatively unavailable in antituberculosis dispensaries. Patients that needed these drugs were directed to specialized Federal antituberculosis institutions. The study was aimed to evaluate remote results of the treatment of patients with drug-resistant pulmonary tuberculosis who had previous ineffective therapy at a local antituberculosis dispensary and directed to specialized Federal antituberculosis institutions. A total of 143 patients of both sexes aged 20-60 years old were examined. These patients received therapy at the Tver Regional Clinical Antituberculosis Dispensary in 2010-2014. To increase adherence to the treatment, a complex of measures were taken that included an individual session with a specialist, organization of communication with other patients that received effective therapy for tuberculosis, and watching of an educational video. A complex of measures on an increase in the adherence to the treatment among patients with pulmonary tuberculosis provided positive results in 143 patients. These patients agreed to possible surgical intervention in the Federal Antituberculosis Institution. After the surgical treatment, cavity closure and/or abacillation were registered in 132 patients. Adherence to the consumption of antituberculosis drugs significantly increased in the studied patients.

Keywords: Pulmonary tuberculosis, anti-tuberculosis treatment, anti-tuberculosis drugs.

Резюме. Отдаленные результаты лечения у больных туберкулезом легких при неэффективности предшествующей терапии

До недавнего времени бедаквилин и линезолид были относительно недоступны в условиях противотуберкулезных диспансеров, пациентов, которые нуждались в таком лечении направляли в специализированные Федеральные противотуберкулезные учреждения. Целью исследования явилось изучение отдаленных результатов лечения больных лекарственно резистентным туберкулезом легких при неэффективности предшествующей терапии в противотуберкулёзном диспансере и направлении в специализированное Федеральное противотуберкулезное учреждение. Обследованы 143 человек обоего пола в возрастной группе от 20 до 60 лет, получавшие лечение в Тверском областном клиническом противотуберкулезном диспансере в 2010-2014 гг. В процессе повышения приверженности к лечению использовали индивидуальную беседу, организацию общения с другими больными, получившими эффективное противотуберкулезное лечение, просмотр обучающего видеофильма. При проведении мероприятий по повышению приверженности к лечению среди больных туберкулезом легких положительный результат получен у 143 человек, эти больные согласились на возможное хирургическое вмешательство в Федеральном противотуберкулезном учреждении. Непосредственно после хирургического этапа лечения достигнуто закрытие полостей распада и/или абациллирование у 132 человек. Дисциплинированность больных в приеме противотуберкулезных препаратов значительно повысилась.

Ключевые слова: Туберкулез легких, противотуберкулезное лечение, противотуберкулезные препараты. 
Rezumat. Rezultatele pe termen lung ale tratamentului pacienților cu tuberculoză pulmonară în cazul ineficacității terapiei anterioare

Până de curând, bedaquilina și linezolidul erau relativ indisponibile în dispensarele de tuberculoză. Pacienții care aveau nevoie de un astfel de tratament erau îndrumați către unități federale specializate pentru tuberculoză. Scopul studiului a fost de a studia rezultatele pe termen lung ale tratamentului pacienților cu tuberculoză pulmonară rezistentă la medicamente cu ineficacitate a terapiei anterioare într-un dispensar antituberculos și trimiterea către o instituție federală specializată antituberculoză. Studiul a implicat 143 de persoane de ambele sexe în grupa de vârstă de la 20 la 60 de ani, care au primit tratament la Dispensarul Clinic Regional din Tver pentru perioada 2010-2014. În procesul de creștere a aderenței la tratament, am utilizat conversație individuală, a fost organizată comunicarea cu alţi pacienți care au primit un tratament eficient împotriva tuberculozei și au urmărit un videoclip de antrenament. În rezultatul realizării a măsurilor de creștere a aderenței la tratament în rândul pacienților cu tuberculoză pulmonară, s-a obținut un rezultat pozitiv la 143 de pacienți, care au fost de acord cu o posibilă intervenție chirurgicală în cadrul Instituției Federale Antituberculoză. Imediat după etapa chirurgicală a tratamentului, s-a realizat închiderea cavităţilor de distrucție și/sau abacilare la 132 de persoane. Disciplina pacienților în administrarea medicamentelor antituberculoase a crescut semnificativ.

Cuvinte cheie: Tuberculoză pulmonară, tratament antituberculos, medicamente antituberculoase.

\section{Introduction.}

Political leaders worldwide took part in the meeting of the United Nations General Assembly on the issue of tuberculosis in September 2018 and adopted a declaration with obligations to reveal and treat 30 million patients [2].

Drug resistance is a problem for the global control of tuberculosis. In patients with drug-sensitive tuberculosis, the rate of lethality is $6 \%$, while in patients with drug-resistant tuberculosis, the lethality rate is $57 \%$. The adjusted death odds ratio in this group is very high (95\%) [3].

Ethiotropic therapy of tuberculosis is based on the application of chemotherapeutic drugs that exert toxic effects on various systems and organs of patients with tuberculosis [1,5]. In 2018, some key revisions were made in the recommended treatment protocol for tuberculosis in patients with multiple drug resistance and the priority of oral drugs over injection forms was established. For the first time in history, a completely new oral 20-months treatment plan was proposed. The treatment plan includes bedaquiline and linezolid together with levofloxacin/moxifloxacin, cycloserine/clofazimine [4]. This treatment plan differs from the standard $4^{\text {th }}$ protocol of chemotherapy accepted in Russia (MDRTB). Until recently, bedaquiline and linezolid were relatively unavailable in antituberculosis dispensaries. Patients that needed these drugs were directed to specialized Federal antituberculosis institutions. Aim: The study of remote results of the treatment for drug-resistant pulmonary tuberculosis in patients with previous ineffective therapy in an antituberculosis dispensary and directed to a specialized Federal Antituberculosis Institution.

\section{Materials and Methods.}

A total of 143 patients of both sexes aged 20-60 years old were included in the study that received therapy at the Tver regional clinical antituberculosis dispensary in 2010-2014. The main criterion of se- lection was ineffective therapy within not less than 6 months in the conditions of the antituberculosis dispensary (persisting destruction cavities and bacilli elimination, lack of a significant clinical-radiological dynamic). The duration of the disease from the moment of registration in the antituberculosis institution was from 6 months to 24 years (on average, 3.9 years old). The ineffectiveness of previous antituberculosis therapy in these patients provided the basis for a decrease in the adherence to treatment, disbelief in the positive outcome, systemless and irregular intake of the indicated antituberculosis drugs.

Elimination of bacilli in the expectoration detected in 109 patients $(76.2 \%)$; in $74(51.7 \%)$ of them, multiple drug resistance (MDR) was revealed; in 19 (1.3.\%) of them, tuberculosis ultra resistance was registered; and in $16(22.1 \%)$ of them, resistance to $2-4$ drugs was revealed (but not isoniazid and rifampicin simultaneously). In total, the majority of patients (93 patients $-65.0 \%$ ) had multiple and ultra antituberculosis drug resistance revealed before surgery. In 34 patients, there was no bacilli elimination detected. This did not exclude drug resistance because the disease progressed even after the treatment with 1 drug of the first line. In further, drug sensitivity was evaluated during the bacteriological study of the surgical material).

Episodes of bloody expectoration were registered in 24 (16.8\% of patients). The associated diabetes mellitus was observed in $89(62.2 \%)$ patients and craniocerebral injury was in the anamnesis of 48 $(33.6 \%)$ of patients.

By the character of the tuberculosis process, destructive forms prevailed. In $83(58.0 \%)$ patients, fibrous-cavernous pulmonary tuberculosis was diagnosed; in 17 (11.9\%) patients, cavernous pulmonary tuberculosis was revealed; and in 43 (30.1\%) patients, decayed tuberculomas were registered. By the character of the development of tuberculosis process, progressing at the time of direction to the Fed- 
eral Antituberculosis Institution was registered in 104 (72.7\%) patients. In 106 patients directed to the Federal Antituberculosis Institution, the $2^{\text {nd }}$ group of disability was established because of tuberculosis.

Because of drug resistance and ineffective therapy, the patients were directed to the University Clinical Hospital of the Sechenov First Moscow State Medical University (2010-2014) to be advised on the tactics of further treatment. Surgical treatment was recommended in the Sechenov First Moscow State Medical University with the correction of the chemotherapy plan for the treatment of tuberculosis.

\section{Results.}

To increase adherence to the treatment, a complex of measures was taken that included an individual session with a specialist, organization of communication with other patients that received effective therapy for tuberculosis, watching of an educational video "Tuberculosis. Information for patients with tuberculosis", and study of the educational brochure "School of a patient. Brochure for patients with tuberculosis" developed by a charity institution "Partners in Health". These measures aimed to reduce tension, anxiety, and uncertainty, improve communicative skills, and obtain patterns of adaptive coping mechanisms from other patients with tuberculosis. The first step in the increase in the adherence to the treatment included watching a video film "Tuberculosis: answers and questions". The video was divided into three parts because it was difficult for patients, who were taking antituberculosis drugs, especially, isoniazid, to cope with watching it without breaks. After that, patients could ask questions and discuss certain issues associated with tuberculosis and its treatment. For further self-education, patients were recommended the brochure "School of a patient. Brochure for patients with tuberculosis". To watch the video and get familiar with the brochure, a laptop was used, which was evaluated by patients as a more convenient means of getting information. Further, patients were presented who received effective antituberculosis therapy so that could share the experience with patients who had previous ineffective tuberculosis therapy. Such meetings were performed once per week to provide patients with a possibility to think over the obtained information and come up with new questions.

All patients underwent surgical treatment in the University Clinical Hospital of the Sechenov First Moscow State Medical University. The volume of surgical intervention corresponded with the character and spread of the main process. Pneumonectomy (or surgery of complete resection of the lung after preseeding resections) was performed in $32(22.4 \%)$ patients, correcting thoracoplasty - in $66(46.2 \%)$ patients, therapeutical thoracoplasty - in 17 (11.9\%) patients, combined resection - in $29(20.3 \%)$ patients, lobectomy - in $34(23.8 \%)$ patients, and atypical resections - in 24 (16.8\%). Some patients had bilateral resections, and some patients had consecutive stepby-step surgeries.

The operational material underwent pathohistological and bacteriological studies. In 29 (85.3\%) out of 34 patients that did not have the spectrum of drug resistance identified because of the lack of bacilli elimination in the expectoration, positive bacteriological and/or PCR test results were positive. In 25 out of these 29 patients, MDR was revealed, and in 4 patients, preserved sensitivity to the drugs of the first line was detected. Thus, in total, MDR/TB-UR of the infectious agent was revealed in the expectorations/ surgical material of $118(82.5 \%)$ patients. Right after the surgical stage, cavities closure was and/or abacillation was registered in $132(92.3 \%)$ patients. In the postoperative period, antituberculosis therapy continued according to the drug resistance of the infectious agent, usually, by an individual (IV or V) plan.

However, some patients remained nonadherent to the postoperative chemotherapy. It was impossible to form adaptive strategies of coping behavior and increase the adherence to the treatment in them. A year after the surgery, seven patients had a recurrence of the disease. Thus, the effectiveness of the formation to adherence to the treatment, adaptive coping behavior strategies, and effective treatment outcome was observed in 125 (87.4\%) patients.

Remote results were evaluated as per September, $1^{\text {st }} 2019$, i.e. not less than 5 years after the surgical stage of treatment. It was revealed that by that time, $121(84.6 \%)$ patients were transferred into three groups of dispensary monitoring or taken off the register because of the disease resolution. Twelve (8.4\%) patients continued the treatment. In seven of them, stage resections of the single remaining lung were performed. Ten $(7.0 \%)$ patients died because of tuberculosis process progression. As of September, $1^{\text {st }} 2019$, five patients remained in the $2^{\text {nd }}$ group of disability, and according to the decision of the Disability Determination Services, were acknowledged employable. Along with employment capability restoration, reproductive rehabilitation was also observed. In seven former patients (five women and two men), children were born. During pregnancy, women underwent complex examinations to verify the absence of tuberculosis process and to reveal the contraindications to pregnancy. The indication of antituberculosis therapy was not required in either of the cases. It can be stated that among earlier ineffectively treated patients with pulmonary tuberculosis with the prevalence of MDR/ 
TB-UR of the infectious agent and that received complex therapy with surgical stage, the preservation of life and employment rehabilitation were achieved. Besides, the reproductive function was restored.

\section{Conclusion.}

Complex measures on the increase in the adherence to the treatment among patients with pulmonary tuberculosis had a positive outcome in 143 cases. These patients agreed to possible surgical intervention in the Federal Antituberculosis Institution. Right after the surgical stage of the treatment, cavity closures and/or abacillaltion were registered in 132 (92.3\%) patients. In the postoperative period, antituberculosis therapy continued according to the drug resistance of the infectious agent. The adherence to the treatment significantly increased. Some of the patients in this group remained nonadherent to the post-operative chemotherapy. A year after the surgery, seven patients had a recurrence of this disease. In total, five years after the surgical intervention, among patients with previous ineffective therapy for pulmonary tuberculosis, $121(84.6 \%)$ patients were cured of the disease due to the formation of adherence to the treatment and acquiring adaptive strategies of coping behavior. The majority of patients that were earlier registered as the $2^{\text {nd }}$ group of disability were acknowledged by the Disability Determination Services as employable. In seven patients, children were born. Thus, in patients with MDR/TB-UR and pulmonary tuberculosis, surgical intervention is an important element of diagnostic (identification of drug resistance of the infectious agent, which is important for further effective chemotherapy) and treatment that provided cure from tuberculosis for $84 \%$ of patients and their medical, employment, and reproductive rehabilitation.

\section{References}

1. Рясенский Д.С., Гришкина Н.А., Асеев А.В. Влияние туберкулезной инфекции и противотуберкулезной химиотерапии на липидный состав плазмы крови. Эпидемиология и инфекционные болезни. -2018 ; 23(5): 220-224

2. Eskild P.J., Farah M.J., Giuseppe I, Alimuddin Z. Latent tuberculosis infection: diagnostic tests and when to treat. Lancet Infect Dis 2019; 19: 231-234.

3. Kathrin Z, Marie B, Prof L.F., Sonia B, Peter M.K., Joachim G, et al. Drug susceptibility testing and mortality in patients treated for tuberculosis in high-burden countries: a multicentre cohort study. Lancet Infect Dis 2019; 19: 298-307.

4. Timothy D.H., Isobella H, Marc L, Alimuddin Z Revolutionary new treatment regimens for multidrug-resistant tuberculosis. Lancet Infect Dis 2019; 19: 233-235.

5. Рясенский, Д. С. Клиническая эффективность применения препаратов, содержащих глицирризиновую кислоту, у больных туберкулезом легких / Д. С. Рясенский, А. В. Асеев, Н. А. Гришкина // Туберкулез и социально-значимые заболевания. - 2019; 4: 27-31. 